\title{
Fostering Innovative Entrepreneurship Education in Vocational Colleges by Counselors from "Internet +" Perspective
}

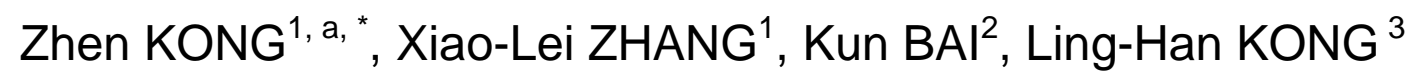 \\ ${ }^{1}$ Beijing Information Technology College, No. 5, Fangyuanxilu, Chaoyang District, Beijing, China \\ ${ }^{2}$ University of International Relations, No. 12, Poshangcun, Haidian District, Beijing, China \\ ${ }^{3}$ Beijing Bayi School, No. 29, Suzhoujie, Haidian District, Beijing, China \\ a'Kongz@bitc.edu.cn \\ *Corresponding author
}

Keywords: Entrepreneurship education; innovation; education; counselors; training.

\begin{abstract}
The entrepreneurship education implementation program in vocational colleges should create a cultural atmosphere conducive to innovation and personnel training based on campus culture, to establish an open course system of entrepreneurship education, to enrich the practice of entrepreneurship education system taking school-enterprise cooperation as a platform, and to build an entrepreneurship education counselor team with double quality relying on training. They plan instruction, select materials, and most powerfully affects what students learn. The paper presents the results of a quantitative survey aimed at identifying the attitudes of educators to innovations. The results suggest enhancing the teacher's core competence structure in the mode of teaching. The cross-over of Internet and other industries will be of enormous value to the development of innovative entrepreneurship education.
\end{abstract}

\section{Introduction}

In both developed and developing parts of the world, knowledge-based development is recognized as a vehicle securing the stability and dynamics of the economy. As universities have become more market focused, they have changed dramatically. Scholars, policymakers, and practitioners now recognize that counselors are central to successfully improving student learning and innovation. Whatever curricula and materials are available, whatever policies are in place, whatever support the parents and community members offer, counselors are ultimately the ones who engage with students. The theory of educational change should be viewed as a concept and a source of supportive arguments that might help counselors get a better insight into their feelings related to the topics and issue. Teaching Entrepreneurship further validates the future of this incredibly vital field. Meanwhile, there are more changes from the initiatives of individual teachers, pupils, parents, or entrepreneurs. Counselors should be viewed as the main factors, agents, and/or recipients of educational change.

\section{Survey Analysis}

At present, entrepreneurship is of fundamental importance for our society. Entrepreneurial companies contribute to economic welfare as they increase the innovative capacity of the economy. These enterprises also lead to more flexible markets and intensified competition. Moreover, through entrepreneurship, new businesses and jobs are created [1]. Counselors represent the main factor of whether a kind of equilibrium and balance between the necessity of innovation and necessity continual development. We opt for a quantitative research by on-line questionnaire. The questionnaire comprises 20 items in the form of self-evaluation scales of the Likert type. The answers are given on a five point scale. The obtained data is analyzed using the methods of descriptive and verification statistics in the application SPSS. It shows that it is the usefulness of the training for students which received the best score. The pedagogues believe that their work is meaningful and they consider it useful and beneficial. 51.5\% counselors welcome a change in respect and support of their superiors and like to innovate in the area of communication with other people participating at the realization of practical training. $43.6 \%$ wish for changes in time and space 
management. 34.3\% wish for innovations in the area of principles and objectives and $20.6 \%$ in the area of staffing. The proposals prove that despite the lack of support, counselors focus on the efficiency of practical training and its usefulness for students.

\section{"Internet Plus" to Fuel Innovation}

China has been transforming from a follower into a major player in the world's Internet industry during the past two decades. The next decade will be a time for the Chinese Internet to broaden its reach globally. The notion of "Internet Plus" mentioned by Premier Li Keqiang has drawn wide attention as a sign of the government's increasing emphasis on the Internet industry. The action plan integrates mobile Internet, cloud computing, big data and the Internet of Things with modern manufacturing, to encourage the healthy development of e-commerce, industrial networks, and Internet banking, and to help Internet companies increase their international presence. The promotion of trans-boundary integration of the Internet and traditional industries through online platforms and IT technology has become a focus of education. The Internet is also a driving force for the transformation of traditional education by counselors. According to China Internet Network Information Center, China had 688 million Internet users by the end of 2015, and some 620 million used cell phones to get online. The Internet penetration rate reached $50.3 \%$. Mobile Internet created new forms of social life. The Internet is not only reshaping the economy, society and governance, but is also creating new opportunities to connect China and the rest of the world. With the help of Internet, China will pursue its education development opportunities with a global vision. Fostering technology transfer (through licensing or sale of intellectual property (IP) rights) from colleges to private companies would facilitate the collaboration between the scientific community and business operators. To ensure a more effective commercialization and foster the innovation-based entrepreneurship, stakeholders need to encourage industry-science linkages. The business community should be more actively involved in advising on curricula. At the same time, curricula in scientific subjects should include courses on entrepreneurship training. Business angels and venture capital firms, have emerged to address the specific financing challenges of innovative companies. In particular, science parks, having the advantage of proximity to colleges, enable the local economies to reap the synergic effect of clustering small innovation-based enterprises, public research institutions and larger companies. In addition, there are three dimensions to change: possible use of new or revised materials, possible use of new teaching approaches, strategies or methodologies, possible change in beliefs[2]. Change can take time and that effective staff development occurs when individuals work in teams, reflecting on progress and receiving constructive feedback and coaching[3]. Change is a developmental process, that individuals move through defined levels of use and that they are unlikely to move at the same rate or in a linear fashion [4]. To be effective teachers requires appropriate support and training. Viewing students as active participants in the learning process and personalizing teaching and assessment to better suit individual student needs require time and space to engage in these practices, as well as the support and training to learn them. It offers suggestions that could be usefully used to help practitioners address challenges in their classrooms. A major obstacle to innovation and commercialization seems to be the insufficient communication and collaboration between the scientific community and industry. Thus, effective interaction between innovation stakeholders is a key to success. Modern computer-related technologies are dependent on many contextual factors to function. It is essential to understand the enabling conditions of certain technologies. As a synthesis, effective technology professional development should draw on counselors' own creativity, draw on school resources (expertise of other teachers), and be delivered in the local context (in the classroom or school lab) [5].The environment for innovation in China will be greatly improved. The Internet not only overturn' traditional sectors, but helps them to be more efficient and stimulates them to grow.

\section{Guide for Innovation}

Of course, entrepreneurship can be taught. Using scholarly research lays the foundation, and educators have crafted a set of practices to foster entrepreneurial thinking that should be incorporated in all courses 
across the entire curriculum. A system of innovation may be thought as a set of actors that interact in the generation, diffusion and use of knowledge in the production process. Taking advantage of knowledge spillovers, these sources provide the know-why and know-how for entrepreneurial success. Closer links between industry, academia and colleges could take the form of training and re-training of practitioners from industry. Network arrangements of different kinds assist counselors to provide meaningful guidelines for potential student entrepreneurs. Teaching is a complex and demanding profession. Three relevant themes emerged: choosing teaching as a profession; growing the passion for teaching and sustaining passion for teaching. Sustaining a passion needs professional development, cluster meeting support and stability of the curriculum[6]. A quality education is the cornerstone to a successful career. Education is effective when it is ongoing. Education is effective when it returns all of us to the basic skills of selling, listening, management, team building and accountability and requires us to practice what we learn with consistency. The entrepreneurship consciousness is the personal psychological bias which plays driving motivation role on entrepreneur in the innovation and entrepreneurship practice activities.

\section{Creating Conductive Environment}

A conducive environment is one in which learning does not take place solely in an instructional context. The key challenge is therefore to create an environment where participants can learn to learn in the way which will be demanded of them in entrepreneurial circumstances. Entrepreneurship can be brought forward the environment in which the knowledge will be used and therefore facilitating learning as part of the doing process. This has implications not only for the way that the classroom is organized, but also for the way knowledge is organized by institutions, the contexts for knowledge that are applied and the values and beliefs that may underpin learning approaches. The development of an approach that focuses more upon adding value to the experience that individuals already have. Much of the new learning will be by doing and responsibility for learning and self-development rests with themselves. Counselors need to encourage students to make sense of things from their experience and feed this into the explicit learning process. This requires a full analysis of what each of the behaviors might mean. For example, opportunity finding behaviors may embrace: creative problem solving; harvesting ideas from competitors and peer businesses; undertaking detailed ongoing customer analysis and communication; internal brainstorming; research and development; use of the world wide web; attendance at exhibitions; and travel abroad. Such an analysis provides an agenda as to the kinds of how to that should be brought into the education programme. This presents an intellectual as well as personal challenge to the teacher[7]. The environment for innovation in China will be greatly improved.

\section{Summary}

China has entered a crucial period for deepening reform and restructuring after the economy registered its lowest pace of growth in 24 years. The quality and accomplishments achieved in entrepreneurship education depend largely on the counselors' comprehensive qualities. For these reasons, colleges should explore the effective ways to construct a good teaching staff with entrepreneurship consciousness and practical ability, should establish the counselors ' training mechanism and incentive mechanism. On the one hand, colleges should select a group of double-qualified backbone counselors. Meanwhile, colleges should support counselors to leave off campus for getting exercise, encourage them to take part in the innovation and entrepreneurship practice activities of industries, enterprises and scientific research institutes. Full-time and part-time counselors engage in innovation and entrepreneurship education together. So there will be a large number of experts with rich career experience of innovation, acting as students' mentors. Our long-term collective quality of life depends on the quality of our schools. Creating conducive environments for learning and entrepreneurship deal with enjoying uncertainty and complexity. Administrators develop and exercise management and leadership skills, become more interactive and collaborate with teachers in order to plan and monitor school-level progress. It is widely expected that educational research should generate knowledge that is relevant for the day-to-day practice of educators. They want knowledge that can inform their actions and activities. The same is true for educational 
policymakers and politicians. All links of the practical teaching of innovation and entrepreneurship education have to be put into the teaching plan, penetrating the whole process of talents cultivating. By these ways, the randomness of some practical teaching links can be contained in the process of teaching.

\section{Acknowledgement}

This research was financially supported by Beijing Information Technology College Research Subject XY-YN-14-201516, by CPC Beijing Municipal Education Committee College Students' Ideological and Political education Project Vocational College Innovative Entrepreneurship Education Mode by Counselors from "Internet +" perspective, and by National Collese Entrepreneurship Education Textbook Project (2014-79-06 and JC16106)

\section{References}

[1] De Clerck \& De Sutter, De Relatie tussen Ondernemerschap en Economische Groei: een Literatuuroverzicht. Steunpunt Ondernemerschap, Ondernemingen en Innovatie, Belgium, 2003.

[2] Fullan, M, The new meaning of educational change, Teachers College Press, New York, 2001, pp.125-139.

[3] Joyce, B.\& Showers B, Student achievement through staff development, Longman, New York, 1995, pp.25-48.

[4] Hall G. E., Dirksen D. J. \& George A. A., Measuring implementation in schools: Levels of use, TX: SEDL, Austin, 2006, pp.25-48.

[5] Elizabeth.A.A Shiburn and Robert E.F Loden, Meaningful Learning Using Technology: What Educators Need to Know and Do, Teachers College Press, New York, 2006, pp.155-179.

[6] Seake Harry Rampa, Passion for teaching: A qualitative study, Procedia-Social and Behavioral Sciences.47(2012)1281-1285.

[7] Allan Gibb, Entrepreneurship: Living with, dealing with, creating and enjoying Uncertainty and Complexity, Industry and Higher Education.6(2002)135-147. 